Paleontological Research, vol. 9, no. 3, pp. 255-270, September 30, 2005

(C) by the Palaeontological Society of Japan

\title{
Japan Sea planktic foraminifera in surface sediments: geographical distribution and relationships to surface water mass
}

\author{
HANAKO DOMITSU ${ }^{1}$ AND MOTOYOSHI ODA ${ }^{2}$ \\ ${ }^{1}$ Division of Environmental Science and Engineering, Graduate School of Natural Science and Technology, Kanazawa University, \\ Kakuma-machi, Kanazawa 920-1192, Japan (e-mail: hana@ge.kanazawa-u.ac.jp) \\ ${ }^{2}$ Institute of Geology and Paleontology, Graduate School of Science, Tohoku University, Aoba, Aramaki, Aoba-ku, Sendai 980-8578, \\ Japan
}

Received January 15, 2004; Revised manuscript accepted September 12, 2005

\begin{abstract}
Modern planktic foraminifera in 51 surface sediments from the Japan Sea, a marginal sea of the western North Pacific, were studied to reveal the relationships between geographical distribution and surface water masses in the Japan Sea. Twenty-four species belonging to 10 genera were identified, of which nine species, namely Neogloboquadrina incompta, Neogloboquadrina pachyderma, Globigerina quinqueloba, Globigerina bulloides, Globigerinoides ruber, Neogloboquadrina dutertrei, Pulleniatina obliquiloculata, Globigerinoides tenellus, and Globigerinita glutinata are predominant. We recognized four geographical distribution patterns of these dominant species that are related to hydrographic conditions in the Japan Sea. The transitional water formed by the mixture between the warm Tsushima Current and cold waters in the Japan Sea is optimal for $N$. incompta, while the distribution of $N$. pachyderma is matched with cold water in the northern Japan Sea. Globigerina quinqueloba and G. bulloides appear to be associated with less saline, nutrient-rich river water from the Changjiang (Yangtze River), and $G$. ruber, $N$. dutertrei, P. obliquiloculata, G. tenellus, and G. glutinata can be regarded as indicators of Tsushima Current water.
\end{abstract}

Key words: Japan Sea, planktic foraminifera, surface sediments, Tsushima Current

\section{Introduction}

The Japan Sea is a semienclosed marginal sea which is connected with the Pacific and adjacent marginal seas through four shallow and narrow straits with sill depths of less than $130 \mathrm{~m}$. At present, the only oceanic water flowing into the Japan Sea is the warm Tsushima Current, which enters through the Tsushima Strait in the south. The Tsushima Current, transporting heat and salt to the surface water, is one of the most important factors in the hydrography of the Japan Sea. However, during the last glacial period the Tsushima Current did not flow into the Japan Sea because the global sea level was remarkably low. Surface water of the Japan Sea has undergone drastic changes over time, including distinct stratification due to lowsalinity surface water during the last glacial maximum and the inflow of the cold Oyashio Current during the period from 15 to $10 \mathrm{kyr}$ BP (Oba et al., 1991, 1995). Corresponding with the changes in surface water, planktic microfossils have significantly changed from the last glacial period to the present time (Oba et al., 1991).

Recently, improved chronology based on accelerator mass spectrometry radiocarbon datings and tephrochronology makes it possible to discuss detailed paleoenvironmental changes during the last $30 \mathrm{kyr}$ (e.g., Kim et al., 2000; Gorbarenko and Southon, 2000; Takei et al., 2002; Ikehara, 2003; Itaki et al., 2004). However, the study of planktic foraminifera has been limited to stable isotope analysis and measurement of the sinistral or dextral coiling ratio of $\mathrm{NeO}$ globoquadrina pachyderma. The abundance and species composition of planktic foraminifera are useful tools for reconstructing past surface-water hydrography, and it is hoped that detailed study of planktic foraminiferal faunal change will help elucidate the paleoenvironmental history of the Japan Sea.

Investigations of relationships between distributions of living assemblages and environmental factors that provide basic data for inferring past environmental conditions are necessary to produce detailed paleo- 
ceanographic reconstructions based on the fossil record. Depth distributions of modern radiolarians or ostracods related to the vertical water structure have been studied using surface sediments and plankton tows from the Japan Sea (Itaki, 2003; Ozawa, 2003). However, data on geographical distributions of planktic foraminifera in Japan Sea surface sediments are limited to the distribution of $N$. pachyderma off Hokkaido (Kitazato, 1978) and preliminary results on species distributions in narrow areas (Oda and Ikehara, 1987, 1988; Oda, 1989, 1991; Oda and Xu, 1992; Domitsu et al., 1999; Tsukawaki et al., 2001). Thus, no comprehensive study of the species distributions of planktic foraminifera in surface sediments across the Japan Sea is available. In this study, we used 51 surface sediment samples systematically collected mainly from the Tsushima Current region in the Japan Sea and examined the relationships between the species distribution of modern planktic foraminifera and the surface water masses.

\section{Oceanographic setting}

The Japan Sea is a marginal sea surrounded by the Japanese Islands, the Korean Peninsula, and the Eurasian continent. It contains the Yamato Rise, three deep basins (the Japan, Yamato, and Tsushima basins), and narrow continental shelves (Figure 1). The average and maximum water depths of the sea are $1350 \mathrm{~m}$ and $3700 \mathrm{~m}$, respectively. The four straits of Tsushima, Tsugaru, Soya, and Tatarskiy, which connect the Japan Sea with the Pacific, the Okhotsk Sea, and the East China Sea, have shallow sill depths of less than $130 \mathrm{~m}$. Because water exchange between adjacent seas is confined to surface water, deep water below 300 to $400 \mathrm{~m}$ depths in the Japan Sea is generally homogeneous, with a low temperature $\left(0^{\circ} \mathrm{C}\right.$ to $0.5^{\circ} \mathrm{C}$ ), low salinity $(34.0 \%$ to $34.1 \%$ ) , and high dissolved oxygen content (5.0 to $5.5 \mathrm{~mL} / \mathrm{L}$ ) (Moriyasu, 1972). This deep water is called the Japan Sea Proper Water (Uda, 1934). In the southern part of the Japan Sea, the Japan Sea Proper Water is covered by the warm surface water of the Tsushima Current. The Tsushima Current water is formed by the mixture between the Kuroshio and East China Sea shelf waters (Lim, 1971; Sawara and Hanzawa, 1979). The Tsushima Current enters the Japan Sea through the Tsushima Strait and flows out mainly to the Pacific through the Tsugaru Strait (Figure 1a). The rest flows northward along the western coast of Hokkaido and out to the Okhotsk Sea through the Soya Strait. After passing through the Tsushima Strait, the Tsushima Current is characterized by strong variabilities created by many meanders and eddies. The warm water of the Tsushima Current is cooled by mixing with cold water as it travels through the Japan Sea (Figure 2a, b). In the northern Japan Sea, the Liman Current flows southward from near the Tatarskiy Strait. The boundary between both currents forms a polar front at latitude $39^{\circ} \mathrm{N}$ to $40^{\circ} \mathrm{N}$.

The salinity around the Tsushima Strait, especially in the western channel, decreases rapidly in summer (Figure 2c, d; Ogawa, 1983; Manda et al., 2000). The main source of this low-salinity water is the fresh water of the Changjiang (Yangtze River), whose discharge accounts for about $90 \%$ of the total river discharge into the Yellow Sea and the East China Sea (Isobe et al., 2002; Chan and Isobe, 2003).

\section{Material and methods}

Surface sediment samples were collected from the central Japan Sea and the southwestern to northeastern parts along the Japanese Islands during cruises of the R.V. Hakurei-maru of the Geological Survey of Japan and R.V. Tansei-maru of the Ocean Research Institute of the University of Tokyo (Table 1; Figure 1b). A grab sampler was used to collect all samples except for sample No. 19, which was obtained with a multiple-core sampler. The uppermost 1 to $2 \mathrm{~cm}$ of surface sediments were used for this study.

The samples were first washed through a $63-\mu \mathrm{m}$ screen, and the retained particles were dried at $40^{\circ} \mathrm{C}$. When planktic foraminifera were relatively abundant, sediments coarser than $63 \mu \mathrm{m}$ were split into smaller aliquots with a microsplitter. Each sample was then dry sieved through a $125-\mu \mathrm{m}$ screen. Planktic foraminifera larger than $125 \mu \mathrm{m}$ were picked out from the aliquots until 100 to 200 planktic foraminiferal specimens had been collected. All these specimens were identified and counted. Foraminiferal assemblages in sediment samples from about $1500 \mathrm{~m}$ and deeper were affected by dissolution because the present carbonate compensation depth (CCD) of the Japan Sea is about $2000 \mathrm{~m}$, much shallower than in the open ocean (Ichikura and Ujiié, 1976). We eliminated samples affected by dissolution and examined the foraminiferal assemblages of 51 surface samples for this study.

\section{Results}

A total of 24 species belonging to 10 genera were identified in the studied 51 samples (Table 2; Figure $3)$. The most dominant species, with maximum percentages greater than $50 \%$, were Neogloboquadrina incompta and $N$. pachyderma. Secondary predominant 


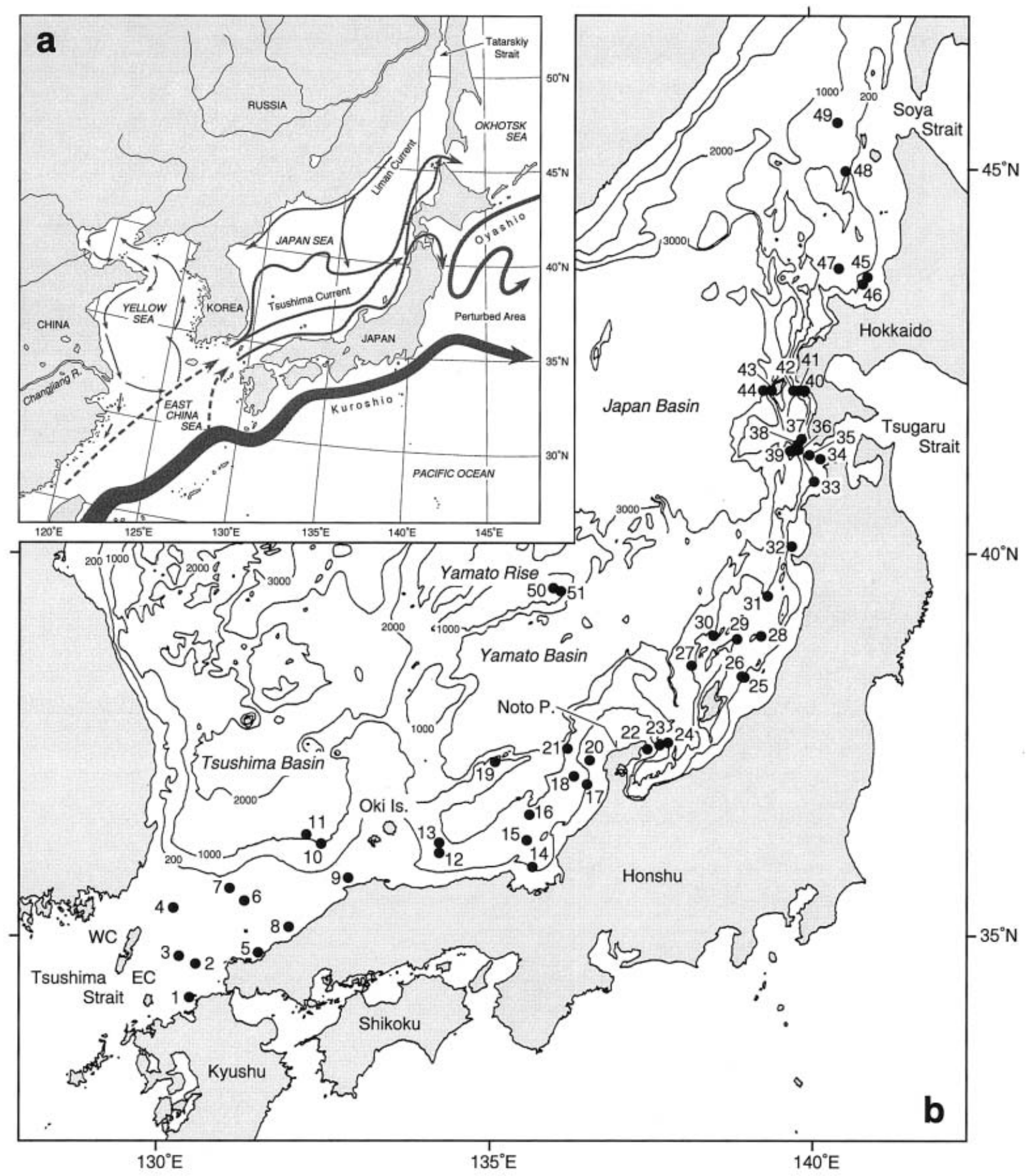

Figure 1. Map (a): Paths of main ocean currents around Japan. Dashed arrows show two hypotheses with respect to the origin of the Tsushima Current. Map (b): Locations of the 51 surface sediment samples (dots) used in this study. WC and EC indicate the western and eastern channels of the Tsushima Strait, respectively.

species, exceeding 30\%, were Globigerina quinqueloba, Globigerina bulloides, and Globigerinoides ruber. These five species accounted for $40 \%$ to $100 \%$ of the planktic foraminiferal assemblage in each sample. Other common species were Neogloboquadrina dutertrei, Pulleniatina obliquiloculata, Globigerinoides 

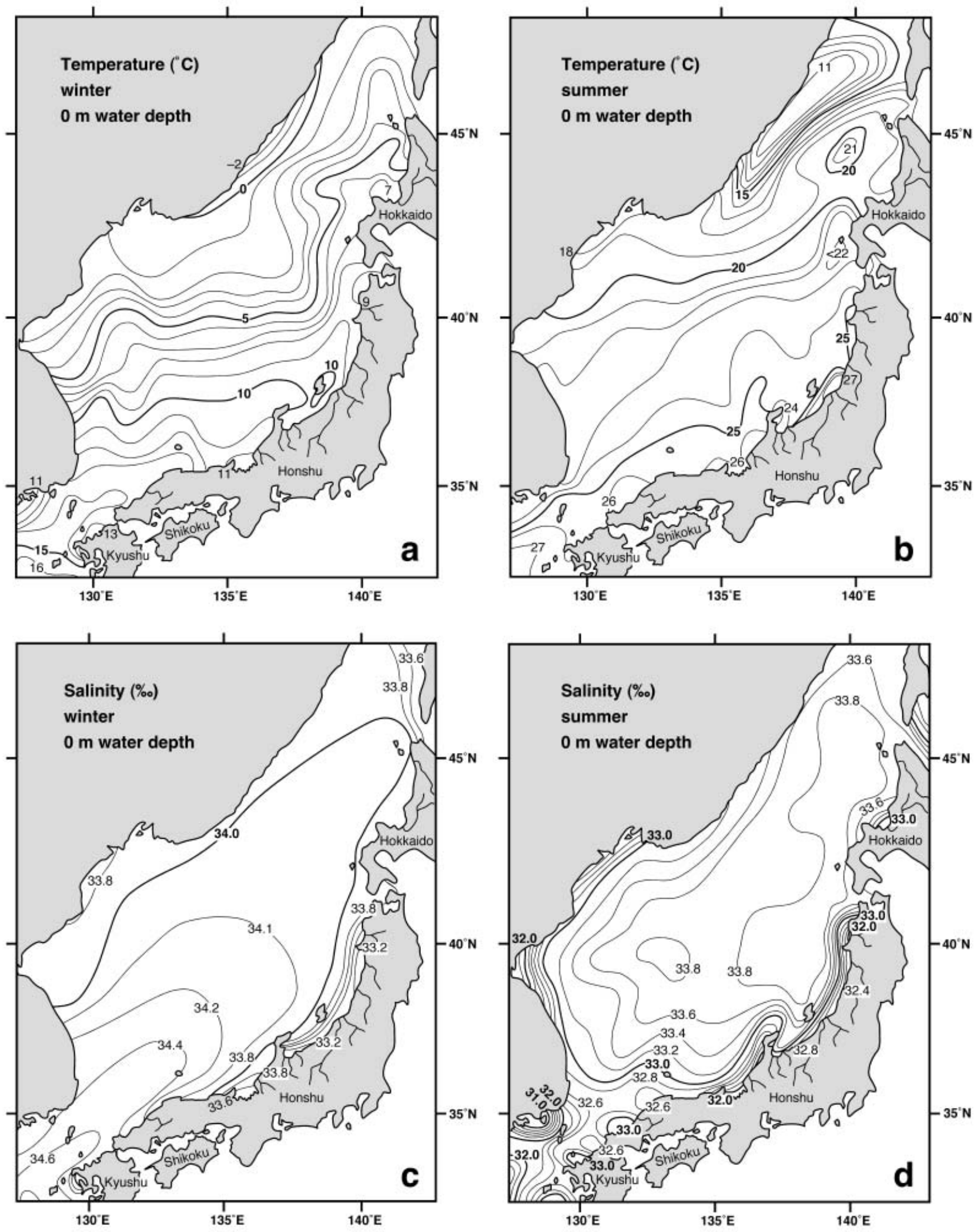

Figure 2. Hydrographic conditions in the Japan Sea in terms of mean values of surface-water temperature and salinity in winter and summer (after Japan Oceanographic Data Center, 1978). Main rivers on the Japan Sea side of Japan are also shown. 
Planktic foraminifera from the Japan Sea

Table 1. Locations and water depths of surface sediment samples used in this study.

\begin{tabular}{|c|c|c|c|c|c|c|}
\hline Sample No. & Cruise & Station & Latitude N & Longitude $\mathrm{E}$ & Water depth $(\mathrm{m})$ & Reference \\
\hline 1 & GH85-2 & 57 & $33^{\circ} 51.08^{\prime}$ & $130^{\circ} 20.86^{\prime}$ & 49 & Ikehara and Kawahata, 1986 \\
\hline 2 & GH85-2 & 64 & $34^{\circ} 20.39^{\prime}$ & $130^{\circ} 23.46^{\prime}$ & 112 & ibid. \\
\hline 3 & GH85-2 & 26 & $34^{\circ} 24.95^{\prime}$ & $130^{\circ} 09.45^{\prime}$ & 110 & ibid. \\
\hline 4 & GH85-2 & 17 & $34^{\circ} 58.82^{\prime}$ & $130^{\circ} 05.40^{\prime}$ & 125 & ibid. \\
\hline 5 & GH85-2 & 231 & $34^{\circ} 30.98^{\prime}$ & $131^{\circ} 21.66^{\prime}$ & 66 & ibid. \\
\hline 6 & GH85-2 & 202 & $35^{\circ} 04.66^{\prime}$ & $131^{\circ} 09.53^{\prime}$ & 116 & ibid. \\
\hline 7 & GH85-2 & 167 & $35^{\circ} 13.50^{\prime}$ & $130^{\circ} 56.31^{\prime}$ & 137 & ibid. \\
\hline 8 & GH85-2 & 350 & $34^{\circ} 53.93^{\prime}$ & $131^{\circ} 49.62^{\prime}$ & 116 & ibid. \\
\hline 9 & GH86 & 65 & $35^{\circ} 33.99^{\prime}$ & $132^{\circ} 41.94^{\prime}$ & 126 & Ikehara et al., 1987 \\
\hline 10 & GH86 & 32 & $35^{\circ} 59.87^{\prime}$ & $132^{\circ} 18.03^{\prime}$ & 873 & ibid. \\
\hline 11 & GH86 & 273 & $36^{\circ} 04.14^{\prime}$ & $132^{\circ} 06.02^{\prime}$ & 1134 & ibid. \\
\hline 12 & GH86 & 222 & $35^{\circ} 57.97^{\prime}$ & $134^{\circ} 12.07^{\prime}$ & 519 & ibid. \\
\hline 13 & GH86 & 223 & $36^{\circ} 03.89^{\prime}$ & $134^{\circ} 12.04^{\prime}$ & 769 & ibid. \\
\hline 14 & GH87-2 & 138 & $35^{\circ} 50.23^{\prime}$ & $135^{\circ} 39.49^{\prime}$ & 218 & Katayama and Ikehara, 1988 \\
\hline 15 & GH87-2 & 120 & $36^{\circ} 10.70^{\prime}$ & $135^{\circ} 34.24^{\prime}$ & 387 & ibid. \\
\hline 16 & GH87-2 & 125 & $36^{\circ} 32.80^{\prime}$ & $135^{\circ} 37.22^{\prime}$ & 707 & ibid. \\
\hline 17 & GH87-2 & 228 & $36^{\circ} 54.01^{\prime}$ & $136^{\circ} 23.98^{\prime}$ & 216 & ibid. \\
\hline 18 & GH87-2 & 230 & $36^{\circ} 59.98^{\prime}$ & $136^{\circ} 15.96^{\prime}$ & 341 & ibid. \\
\hline 19 & KT95-14 & $M-1$ & $37^{\circ} 10.2^{\prime}$ & $134^{\circ} 55.2^{\prime}$ & 1047 & Tsukawaki et al., 1997 \\
\hline 20 & GH88 & 140 & $37^{\circ} 19.41^{\prime}$ & $136^{\circ} 29.35^{\prime}$ & 168 & Katayama, 1989 \\
\hline 21 & GH88 & 53 & $37^{\circ} 30.37^{\prime}$ & $136^{\circ} 08.89^{\prime}$ & 374 & ibid. \\
\hline 22 & GH88 & 165 & $37^{\circ} 25.04^{\prime}$ & $137^{\circ} 23.50^{\prime}$ & 89 & ibid. \\
\hline 23 & GH88 & 168 & $37^{\circ} 29.69^{\prime}$ & $137^{\circ} 38.96^{\prime}$ & 703 & ibid. \\
\hline 24 & GH88 & 169 & $37^{\circ} 31.28^{\prime}$ & $137^{\circ} 44.18^{\prime}$ & 1315 & ibid. \\
\hline 25 & KT99-14 & G-44 & $38^{\circ} 22.9^{\prime}$ & $138^{\circ} 55.7^{\prime}$ & 174 & Tsukawaki et al., 2001 \\
\hline 26 & KT99-14 & G-43 & $38^{\circ} 23.2^{\prime}$ & $138^{\circ} 55.0^{\prime}$ & 202 & ibid. \\
\hline 27 & KT99-14 & G-37 & $38^{\circ} 32.4^{\prime}$ & $138^{\circ} 05.7^{\prime}$ & 1456 & ibid. \\
\hline 28 & GH91 & 262 & $38^{\circ} 55.23^{\prime}$ & $139^{\circ} 16.25^{\prime}$ & 673 & Nakajima and Katayama, 1992 \\
\hline 29 & GH91 & 238 & $38^{\circ} 52.11^{\prime}$ & $138^{\circ} 50.99^{\prime}$ & 736 & ibid. \\
\hline 30 & GH91 & 227 & $38^{\circ} 55.36^{\prime}$ & $138^{\circ} 28.89^{\prime}$ & 956 & ibid. \\
\hline 31 & GH91 & 327 & $39^{\circ} 28.39^{\prime}$ & $139^{\circ} 21.87^{\prime}$ & 830 & ibid. \\
\hline 32 & GH91 & 408 & $40^{\circ} 07.07^{\prime}$ & $139^{\circ} 44.91^{\prime}$ & 73 & ibid. \\
\hline 33 & GH77-3-2 & 110 & $40^{\circ} 58.1^{\prime}$ & $140^{\circ} 07.1^{\prime}$ & 138 & unpublished data (Oda, MS) \\
\hline 34 & GH77-3-2 & 105 & $41^{\circ} 14.0^{\prime}$ & $140^{\circ} 13.0^{\prime}$ & 296 & ibid. \\
\hline 35 & GH77-3-2 & 247 & $41^{\circ} 16.1^{\prime}$ & $140^{\circ} 03.8^{\prime}$ & 252 & ibid. \\
\hline 36 & GH77-3-2 & 255 & $41^{\circ} 20.1^{\prime}$ & $139^{\circ} 51.9^{\prime}$ & 150 & ibid. \\
\hline 37 & GH94 & 1021 & $41^{\circ} 27.88^{\prime}$ & $139^{\circ} 54.97^{\prime}$ & 330 & Inouchi et al., 1995 \\
\hline 38 & GH94 & 1014 & $41^{\circ} 23.86^{\prime}$ & $139^{\circ} 50.06^{\prime}$ & 822 & ibid. \\
\hline 39 & GH94 & 1002 & $41^{\circ} 20.07^{\prime}$ & $139^{\circ} 44.91^{\prime}$ & 536 & ibid. \\
\hline 40 & GH94 & 1059 & $42^{\circ} 06.08^{\prime}$ & $139^{\circ} 57.59^{\prime}$ & 100 & ibid. \\
\hline 41 & GH94 & 1058 & $42^{\circ} 05.93^{\prime}$ & $139^{\circ} 52.59^{\prime}$ & 135 & ibid. \\
\hline 42 & GH94 & 1057 & $42^{\circ} 06.02^{\prime}$ & $139^{\circ} 47.40^{\prime}$ & 939 & ibid. \\
\hline 43 & GH94 & 1054 & $42^{\circ} 06.09^{\prime}$ & $139^{\circ} 22.56^{\prime}$ & 315 & ibid. \\
\hline 44 & GH94 & 95 & $42^{\circ} 04.05^{\prime}$ & $139^{\circ} 14.90^{\prime}$ & 2788 & ibid. \\
\hline 45 & GH96 & 311 & $43^{\circ} 35.98^{\prime}$ & $141^{\circ} 00.09^{\prime}$ & 109 & Katayama et al., 1997 \\
\hline 46 & GH96 & 306 & $43^{\circ} 32.01^{\prime}$ & $140^{\circ} 55.01^{\prime}$ & 118 & ibid. \\
\hline 47 & GH96 & 253 & $43^{\circ} 40.01^{\prime}$ & $140^{\circ} 35.17^{\prime}$ & 782 & ibid. \\
\hline 48 & GH98 & 466 & $45^{\circ} 00.03^{\prime}$ & $140^{\circ} 44.91^{\prime}$ & 285 & Ikehara et al., 1999 \\
\hline 49 & GH98 & 551 & $45^{\circ} 34.20^{\prime}$ & $140^{\circ} 35.05^{\prime}$ & 496 & ibid. \\
\hline 50 & KT99-14 & G-18 & $39^{\circ} 29.1^{\prime}$ & $135^{\circ} 50.6^{\prime}$ & 777 & Tsukawaki et al., 2001 \\
\hline 51 & KT99-14 & G-19' & $39^{\circ} 27.3^{\prime}$ & $135^{\circ} 53.7^{\prime}$ & 1021 & ibid. \\
\hline
\end{tabular}

tenellus, and Globigerinita glutinata. The relative abundance (\%) distributions of these nine species in the study area are shown in Figure 4.

Neogloboquadrina incompta occurred abundantly $(>70 \%)$ in the marginal areas from the Oki Islands to the central part of Hokkaido and decreased to less than $10-20 \%$ in the central part of the Japan Sea and around the Tsushima Strait (Figure 4a).

Neogloboquadrina pachyderma was abundant $(>70 \%)$ in the central and northern parts of the Ja- 


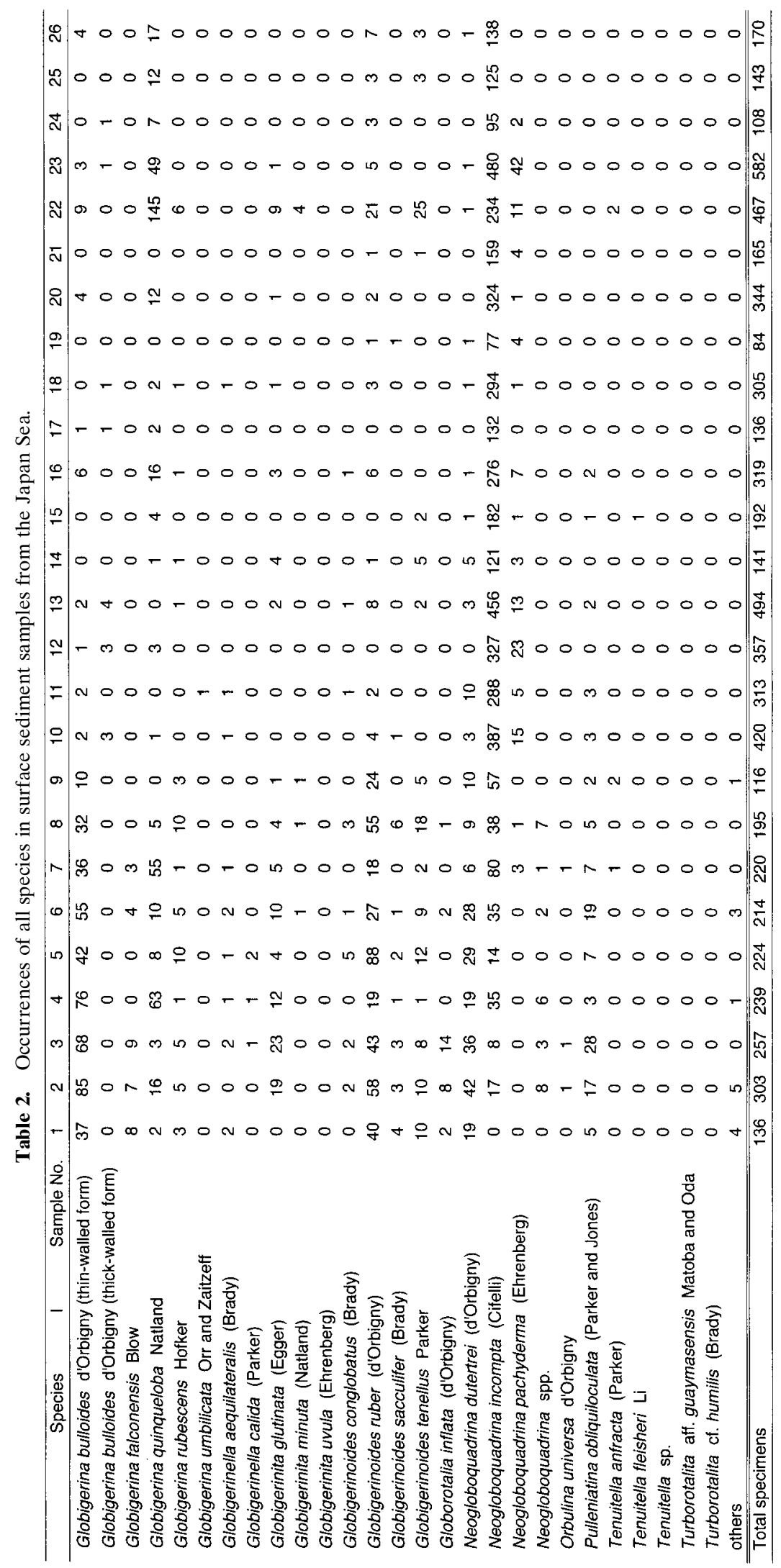




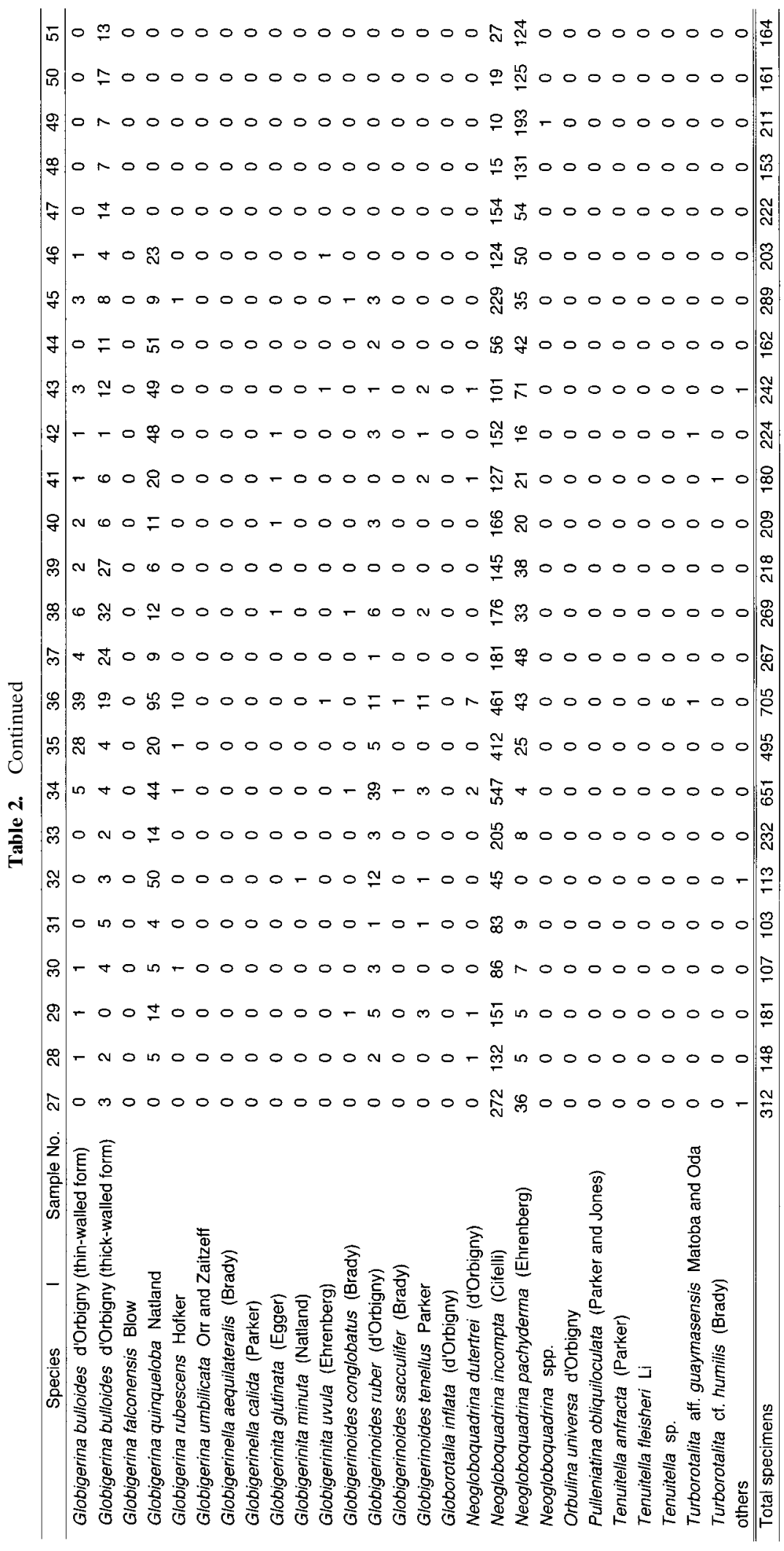



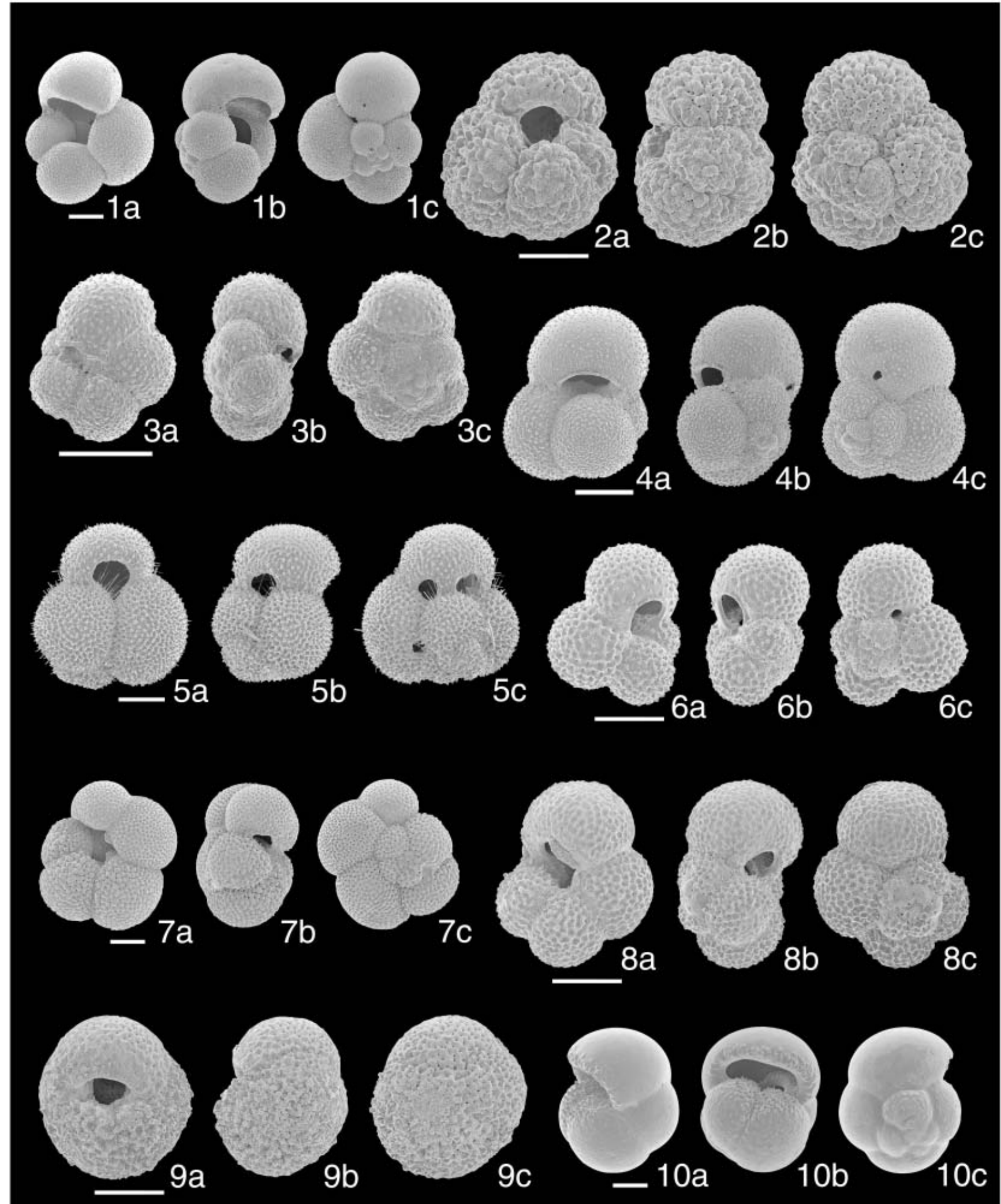
pan Sea and occurred only sparsely $(<10 \%)$ around the continental margin of the Japanese Islands (Figure 4b). This species was frequently absent in many samples around the Tsushima Strait.

The occurrence of $G$. quinqueloba increased in two different areas of the Tsushima Strait $(>20 \%)$ and marginal areas in the Northwest Japan (10-30\%) (Figure 4c).

Globigerina bulloides was abundant $(>20 \%)$ around the Tsushima Strait and sporadically common (3-10\%) in the central part of the Japan Sea and marginal areas off Hokkaido (Figure 4d). Two forms of this species differing in thickness of chamber wall are distinguished (Figure 3). Samples from southwest of the Oki Islands contained mostly thin-walled forms, while thick-walled forms were abundant in the central part of the Japan Sea and marginal areas off Hokkaido (Table 2).

Globigerinoides ruber showed high abundance $(>20 \%)$ around the Tsushima Strait and decreased $(>3 \%)$ rapidly around the Oki Islands (Figure 4e).

Neogloboquadrina dutertrei, P. obliquiloculata, $G$. tenellus, and G. glutinata represented a similar trend to that of G. ruber. These species occurred commonly (generally $>9 \%$ ) around the Tsushima Strait and decreased to less than $3 \%$ around the Oki Islands (Figure 4f-i).

\section{Discussion}

Two distinct patterns, called here Pattern I and II, can be distinguished from these nine geographical distributions. Pattern I occurs frequently within the Japan Sea and corresponds to the areas of distribution of $N$. incompta and $N$. pachyderma. Pattern II shows a high concentration around the Tsushima Strait and generally decreases northeastward along the Japanese Islands. This pattern also includes distributions of the other seven species. Furthermore, distributional patterns I and II can each be subdivided into two supplementary patterns, Ia and Ib and IIa and IIb, respectively. Pattern Ia, marked by predominance of $N$. incompta, is typical in the southeastern Japan Sea, from the Oki Islands to near central Hokkaido (Figure 4j). Pattern Ib is highly prevalent from the central to northern Japan Sea (Figure 4k) and contains high percentages of $N$. pachyderma. Pattern IIa is highly characteristic of the western channel of the Tsushima Strait (Figure 4l) and consists of predominant $G$. quinqueloba and G. bulloides. Pattern IIb occurs frequently in the eastern channel of the strait (Figure 41) and is characterized by the occurrence of G. ruber, $N$. dutertrei, P. obliquiloculata, G. tenellus, and G. glutinata. These four distributional patterns relate closely to the surface water masses (Table 3 ).

\section{Oceanographic implication of Pattern I}

Neogloboquadrina incompta and $N$. pachyderma dominate the modern Japan Sea, suggesting optimal conditions for these species. Pattern Ia corresponds with mid- to downstream regions of the Tsushima Current, where mixing with northern cold water cools the Tsushima Current and numerous meanders and eddies cause great variability. This pattern suggests that $N$. incompta is best suited to the transitional water formed by the mixing of the warm Tsushima Current and cold waters in the Japan Sea. In the western North Pacific off Japan, N. incompta shows high abundance in the perturbed area between the Kuroshio and Oyashio fronts and in the cold-water mass near Kuroshio (Takayanagi and Oda, 1983; Oda and Takemoto, 1992). These results are concordant with those of this study.

Pattern $\mathrm{Ib}$ is associated with the cold-water region north of the polar front in the Japan Sea. Therefore, $N$. pachyderma, the predominant species in this pattern, may be an indicator of cold water in the northern Japan Sea. This species is a dominant species of cold water in polar and subpolar regions (Bé, 1977) and is regarded as a typical marker of the cold Oyashio Current near Japan (Takayanagi and Oda, 1983; Oda and Takemoto, 1992).

\section{Oceanographic implication of Pattern II}

Pattern II correlates with the upstream region of the Tsushima Current. This pattern suggests that the seven associated species are influenced by waters flowing into the Japan Sea through the Tsushima

\footnotetext{
- Figure 3. Selected planktic foraminiferal species in surface sediment samples from the Japan Sea. Specimens of Globigerina bulloides exhibit morphological differences in the thickness of chamber walls.

1. Globigerina bulloides d'Orbigny (thin-walled form), from sample No. 3. 2. Globigerina bulloides d'Orbigny (thick-walled form), from sample No. 38. 3. Globigerina quinqueloba Natland, from sample No. 6. 4. Globigerinita glutinata (Egger), from sample No. 8. 5. Globigerinoides ruber (d'Orbigny), from sample No. 9. 6. Globigerinoides tenellus Parker, from sample No. 5. 7. Neogloboquadrina dutertrei (d'Orbigny), from sample No. 11. 8. Neogloboquadrina incompta (Cifelli), from sample No. 38. 9. Neogloboquadrina pachyderma (Ehrenberg), from sample No. 49. 10. Pulleniatina obliquiloculata (Parker and Jones), from sample No. 3.

a: umbilical, b: side, c: spiral views, scale bars: $100 \mu \mathrm{m}$.
} 

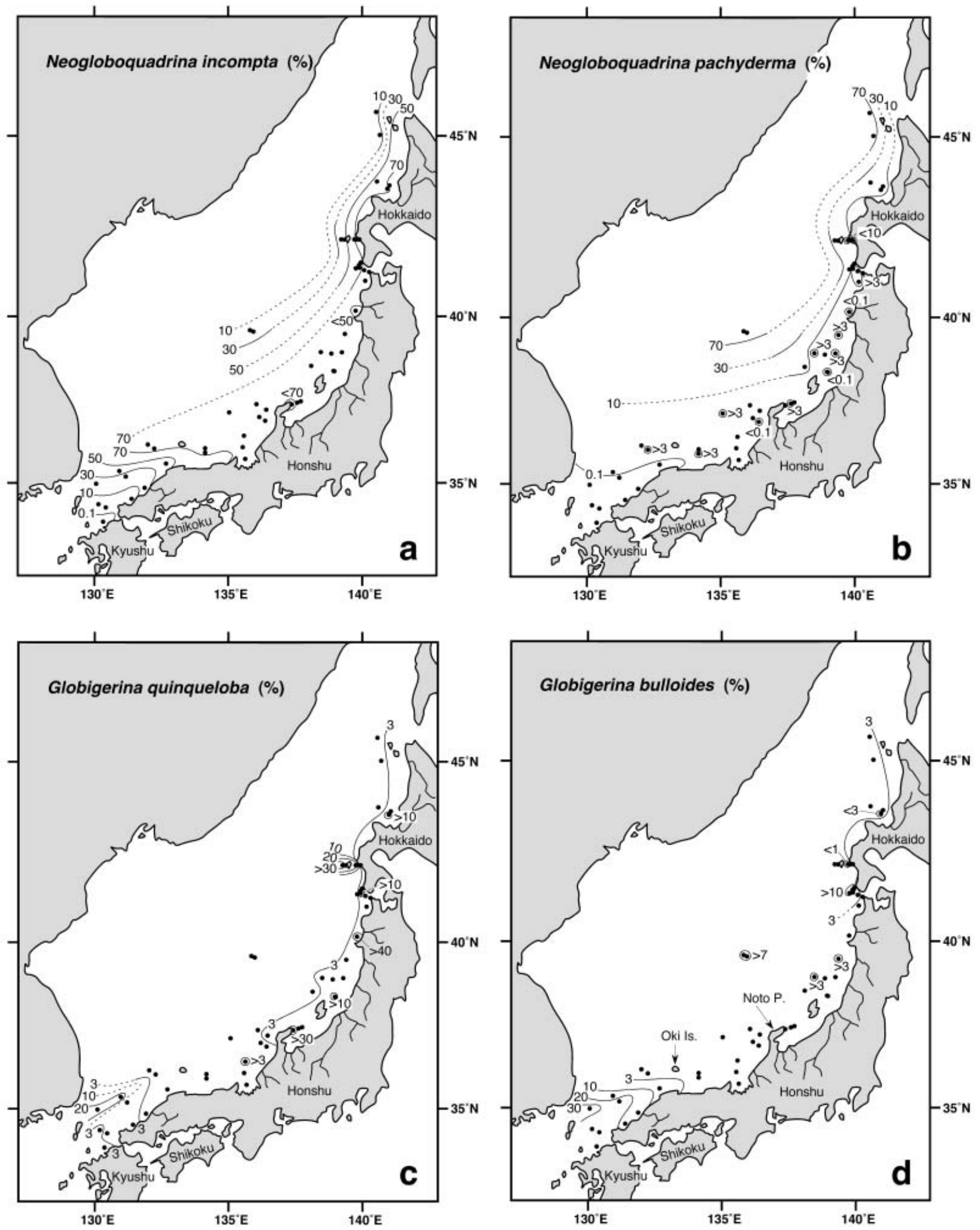

Figure 4. Map (a-i): Distributions of the nine predominant planktic foraminiferal species in surface sediments from the Japan Sea. Values represent \% of total count. Map (j-1): Schematic representation of four patterns of Pattern Ia, Ib, IIa, and IIb distinguished from the geographical distributions of nine major species in this study. Main rivers on the Japan Sea side of Japan are also shown. 
Planktic foraminifera from the Japan Sea
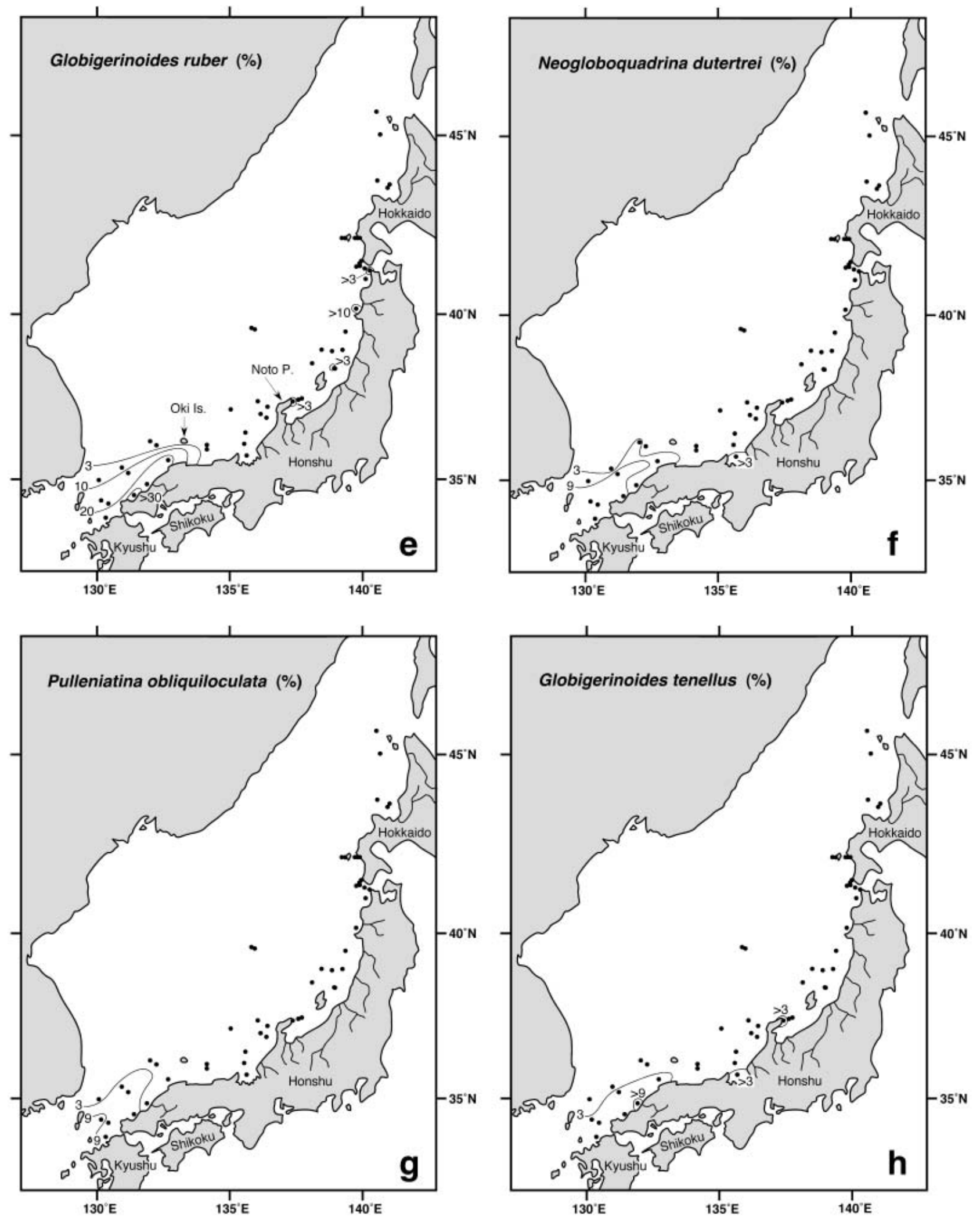

Figure 4. Continued 

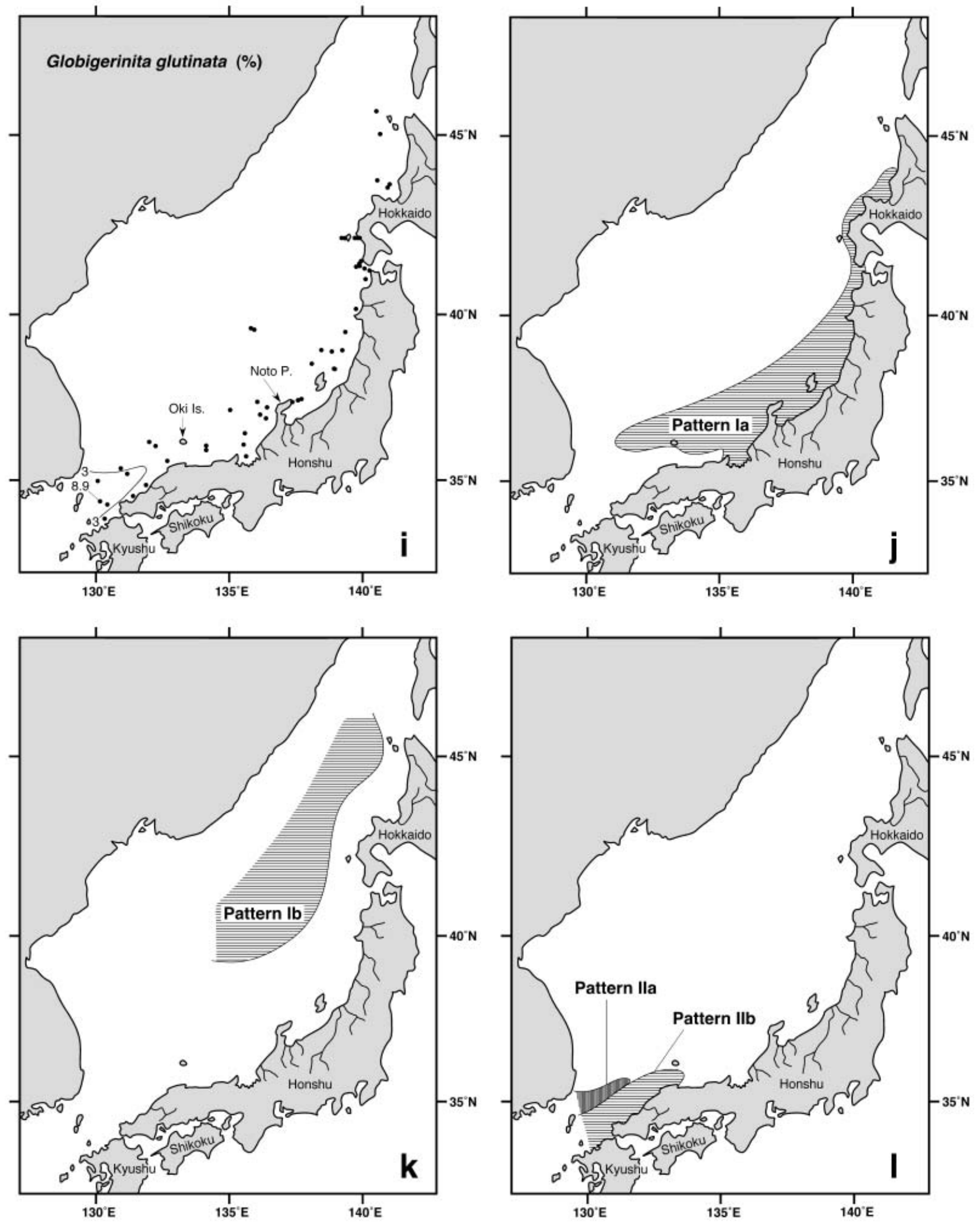

Figure 4. Continued 
Table 3. Summary of the relationships between the geographical distributions of nine major planktic foraminiferal species in surface sediments and surface water masses in the Japan Sea.

\begin{tabular}{|c|c|c|c|}
\hline Species & [pattern] & Geographical distribution & Corresponding surface water mass \\
\hline $\begin{array}{l}\text { Neogioboquadrina incompta } \\
\text { (Figure 4a) }\end{array}$ & $\begin{array}{c}{[\text { la] }} \\
\text { (Figure 4j) }\end{array}$ & $\begin{array}{l}\text { southeastern Japan Sea } \\
\text { (mid- to downstream regions } \\
\text { of the Tsushima Current) }\end{array}$ & $\begin{array}{l}\text { transitional water mixed with } \\
\text { the warm Tsushima Current } \\
\text { and cold waters in the Japan Sea }\end{array}$ \\
\hline $\begin{array}{l}\text { Neogloboquadrina pachyderma } \\
\text { (Figure 4b) }\end{array}$ & $\begin{array}{c}{[\mathrm{lb}]} \\
\text { (Figure 4k) }\end{array}$ & $\begin{array}{l}\text { central to northern Japan Sea } \\
\text { north of the polar front }\end{array}$ & cold water in the northern Japan Sea \\
\hline $\begin{array}{l}\text { Globigerina quinqueloba } \\
\text { Globigerina bulloides } \\
\text { (Figure } 4 \mathrm{c}, \mathrm{d} \text { ) }\end{array}$ & $\begin{array}{c}{[\mathrm{llla]}} \\
\text { (Figure 4l) }\end{array}$ & $\begin{array}{l}\text { western channel } \\
\text { of the Tsushima Strait } \\
\text { (upstream region } \\
\text { of the Tsushima Current) }\end{array}$ & $\begin{array}{l}\text { less-saline and nutrient-rich water } \\
\text { from the Changjiang } \\
\text { which enters via the East China Sea }\end{array}$ \\
\hline $\begin{array}{l}\text { Globigerinoides ruber } \\
\text { Neogloboquadrina dutertrei } \\
\text { Pulleniatina obliquiloculata } \\
\text { Globigerinoides tenellus } \\
\text { Globigerinita glutinata } \\
\text { (Figure } 4 \text { e-i) }\end{array}$ & $\begin{array}{c}\text { [llb] } \\
\text { (Figure 4l) }\end{array}$ & $\begin{array}{l}\text { eastern channel } \\
\text { of the Tsushima Strait } \\
\text { (upstream region } \\
\text { of the Tsushima Current) }\end{array}$ & Tsushima Current water \\
\hline
\end{tabular}

Strait, namely, by the Tsushima Current and Changjiang river water that enters via the East China Sea.

Pattern IIa corresponds with the western channel of the Tsushima Strait, where salinity decreases markedly during the summer due to the input of fresh water from the Changjiang transported from the East China Sea. Thus, G. quinqueloba and G. bulloides may be strongly influenced by less saline and eutrophic water. In the East China Sea, high abundance of G. quinqueloba in surface sediments is restricted to areas near the mouth of the Changjiang (Wang et al., 1988; Xu and Oda, 1999). Globigerina bulloides occurs abundantly in surface sediments from the continental shelf (Xu and Oda, 1999), where primary productivity is remarkably high due to large amounts of dissolved inorganic nutrients from the Changjiang (Hama et al., 1997). Distributions of both species in the East China Sea also reflect the influence of the less saline and nutrient-rich fresh water from the Changjiang. This is consistent with the distributions of both species in the Japan Sea. Globigerina quinqueloba also occurs commonly in the coastal area from the Noto Peninsula to western Hokkaido (Figure 4c). This distribution is probably related to the freshwater input from main rivers along the west coast of Honshu and Hokkaido.

Pattern IIb correlates with the eastern channel of the Tsushima Strait, which is not as strongly affected as the western channel by the fresh Changjiang water. This suggests that the distributions of G. ruber, $N$. dutertrei, P. obliquiloculata, G. tenellus, and G. glutinata relate to Tsushima Current water. These five species are widely distributed in tropical and subtropical regions (Bé, 1977; Saito et al., 1981). In surface sediments from the East China Sea, $N$. dutertrei and $P$. obliquiloculata occur abundantly in the path of the Kuroshio Current (Xu and Oda, 1999; Ujiié and Ujiié, 1999) which is the source of the Tsushima Current water. Globigerinoides ruber and G. glutinata are the main species of the assemblage in surface sediments from the East China Sea (Xu and Oda, 1999) and the predominant species in surface sediments from the Kuroshio area on the margin of the western North Pacific (Oda and Takemoto, 1992). Thus, these five species can be regarded as indicators of Tsushima Current water in the Japan Sea. As G. ruber shows high abundance and occurs continuously to its distribution's northernmost edge off central Hokkaido (Table 2), this species is likely the most important indicator of the Tsushima Current in the Japan Sea.

\section{Conclusions}

Twenty-four species belonging to 10 genera of planktic foraminifera were recognized in 51 surface sediment samples collected mainly from the Tsushima Current region of the Japan Sea. Four distinct patterns were distinguished from the geographical distributions of nine major species of $N$. incompta, $N$. pachyderma, G. quinqueloba, G. bulloides, G. ruber, $N$. dutertrei, P. obliquiloculata, G. tenellus, and $G$. glutinata. Comparing distributional patterns and surface water masses in the Japan Sea revealed the following four relationships between planktic foraminiferal assemblages and hydrographic conditions: 1) $\mathrm{N}$. incompta appears to be an optimal indicator of transitional water formed by mixing of the warm Tsushima Current and cold waters in the Japan Sea; 2) N. pachyderma can be considered an indicator of cold water 
in the northern Japan Sea; 3) G. quinqueloba and $G$. bulloides distributions reflect the strong influence of less saline and nutrient-rich water from the Changjiang which enter via the East China Sea; and 4) $G$. ruber, $N$. dutertrei, P. obliquiloculata, G. tenellus, and G. glutinata can be regarded as indicators of Tsushima Current water. These relationships can be used for a better reconstruction of past conditions in the Japan Sea from the fossil record.

\section{Acknowledgments}

Most samples used in this study were collected during long-term cruises of R.V. Hakurei-maru, Geological Survey of Japan. The authors express their sincere gratitude to K. Ikehara and H. Katayama (National Institute of Advanced Industrial Science and Technology) for providing the opportunity to write this paper and for their shipboard work. We thank the captains, officers, and the entire crew of R.V. Hakureimaru for their shipboard work. Thanks are also due to S. Tsukawaki (Kanazawa Univ.) and S. Hasegawa (Kumamoto Univ.) for providing samples. We thank M. Kato (Kanazawa Univ.) and X. Xu (Japan Agency for Marine-Earth Science and Technology) for helpful advice concerning various aspects of foraminifera. We also thank H. Nishi (Hokkaido Univ.) and I. Motoyama (Univ. of Tsukuba) for their constructive review. This research was partly supported by a Grant-in-Aid for Scientific Research from the Ministry of Education, Science and Culture, Japan (No. 08404030), to M. Oda, and by Kanazawa University's 21st Century COE Program "Environmental Monitoring and Prediction of Long- and Short-Term Dynamics of Pan-Japan Sea Area: Construction of Monitoring Network and Assessment of Human Effects."

\section{References}

Bé, A.W.H., 1977: An ecological, zoogeographic and taxonomic review of recent planktonic foraminifera. In, Ramsay, A. T.S. ed., Oceanic Micropalaeontology, vol. 1, p. 1100. Academic Press, London.

Chang, P.-H. and Isobe, A., 2003: A numerical study of the Changjiang diluted water in the Yellow and East China Seas. Journal of Geophysical Research, vol. 108(C9), 3299, 10.1029/2002JC001749.

Domitsu, H., Murakami, T. and Oda, M., 1999: Preliminary report on planktic foraminiferal assemblages in surface sediments from the eastern part of the Japan Sea off western Hokkaido. In, Ikehara, K. and Okamura, Y. eds., Comprehensive Study on Environmental Changes in the Western Hokkaido Coastal Area and Study on Evaluation of Marine Active Faults, Preliminary Reports on Re- searches in the 1998 Fiscal Year, GSJ Interim Report, no. $M G / 99 / 1$, p. 81-91. Geological Survey of Japan, Tsukuba. (in Japanese)

Gorbarenko, S. A. and Southon, J.R., 2000: Detailed Japan Sea paleoceanography during the last $25 \mathrm{kyr}$ : constraints from AMS dating and $\delta^{18} \mathrm{O}$ of planktonic foraminifera. Palaeogeography, Palaeoclimatology, Palaeoecology, vol. 156, p. 177-193.

Hama, T., Shin, K. H. and Handa, N., 1997: Spatial variability in the primary productivity in the East China Sea and its adjacent waters. Journal of Oceanography, vol. 53, p. 4151 .

Ichikura, M. and Ujiié, H., 1976: Lithology and planktonic foraminifera of the Sea of Japan piston cores. Bulletin of the National Science Museum, Series C (Geology \& Paleontology), vol. 2, p. 151-178.

Ikehara, K., 2003: Late Quaternary seasonal sea-ice history of the northeastern Japan Sea. Journal of Oceanography, vol. 59 , p. 585-593.

Ikehara, K., Katayama, H. and Arita, M., 1987: Surface sediments off San'in region. In, Arita, M., Okuda, Y. and Moritani, T. eds., Preliminary Reports of Geological Mapping Program of the Continental Shelf Areas in Japan in 1986, p. 121-152. Geological Survey of Japan, Tsukuba. (in Japanese)

Ikehara, K., Katayama, H. and Maekawa, T., 1999: Surface sediments in areas extending from off Teshio to the Soya Strait. In, Ikehara, K. and Okamura, Y. eds., Comprehensive Study on Environmental Changes in the Western Hokkaido Coastal Area and Study on Evaluation of Marine Active Faults, Preliminary Reports on Researches in the 1998 Fiscal Year, GSJ Interim Report, no. MG/99/1, p. 6580. Geological Survey of Japan, Tsukuba. (in Japanese)

Ikehara, K. and Kawahata, H., 1986: Surface sediments off Kita-Kyushu and San'in region. In, Nakao, S., Tamaki, K. and Moritani, T. eds., Preliminary Reports of Geological Mapping Program of the Continental Shelf Areas in Japan in 1985, p. 69-102. Geological Survey of Japan, Tsukuba. (in Japanese)

Inouchi, Y., Otsuka, M., Kumon, F., Motoyama, I. and Katayama, H., 1995: Surface sediments off southwest of Hokkaido. In, Okamura, Y. and Inouchi Y. eds., Preliminary Reports of Comprehensive Study on Environmental Changes in the Western Hokkaido Coastal Area in 1994, p. 63-88. Geological Survey of Japan, Tsukuba. (in Japanese)

Isobe, A., Ando, M., Watanabe, T., Senjyu, T., Sugihara, S. and Manda, A., 2002: Freshwater and temperature transports through the Tsushima-Korea Straits. Journal of Geophysical Research, vol. 107(C7), 3065, 10.1029/2000JC000702.

Itaki, T., 2003: Depth-related radiolarian assemblage in the water-column and surface sediments of the Japan Sea. Marine Micropaleontology, vol. 47, p. 253-270.

Itaki, T., Ikehara, K., Motoyama, I. and Hasegawa, S., 2004: Abrupt ventilation changes in the Japan Sea over the last $30 \mathrm{ky}$ : evidence from deep-dwelling radiolarians. Palaeogeography, Palaeoclimatology, Palaeoecology, vol. 208, p. 263-278.

Japan Oceanographic Data Center, 1978: Marine Environmental Atlas, 157 p. Japan Hydrographic Association, Tokyo.

Katayama, H., 1989: Surface sediments around the Noto Peninsula. In, Arita, M. and Okamura, Y. eds., Preliminary Reports of Geological Mapping Program of the Continental Shelf Areas in Japan in 1988, p. 66-98. Geological Survey 
of Japan, Tsukuba. (in Japanese)

Katayama, H. and Ikehara, K., 1988: Surface sediments in areas extending from off San'in to Hokuriku regions. In, Arita, M. and Moritani, T. eds., Preliminary Reports of Geological Mapping Program of the Continental Shelf Areas in Japan in 1987, p. 69-105. Geological Survey of Japan, Tsukuba. (in Japanese)

Katayama, H., Ikehara, K. and Inouchi, Y., 1997: Surface sediments around the Ishikari Bay. In, Inouchi, Y., Komazawa, M. and Kuramoto, S. eds., Preliminary Reports of Comprehensive Study on Environmental Changes in the Western Hokkaido Coastal Area in 1996, p. 152-175. Geological Survey of Japan, Tsukuba. (in Japanese)

Kim, J.-M., Kennett, J. P., Park, B.-K., Kim, D. C., Kim, G. Y. and Roark, E. B., 2000: Paleoceanographic change during the last deglaciation, East Sea of Korea. Paleoceanography, vol. 15, p. 254-266.

Kitazato, H., 1978: Distribution of the Globigerina pachyderma (Ehrenberg) in the Kuril and Japan Basins, and the fluctuation of coiling direction of G. pachyderma in the core P109. In, Honza, E. ed., Geological Investigation of the Okhotsk and Japan Seas off Hokkaido June-July 1977 (GH77-3 Cruise), Geological Survey of Japan Cruise Report, no. 11, p. 56-59. Geological Survey of Japan, Kawasaki.

Lim, D.-B., 1971: On the origin of the Tsushima Current water. The Journal of the Oceanological Society of Korea, vol. 6, p. 85-91.

Manda, A., Isobe, A., Omura, K. and Kyozuka, Y., 2000: Lowfrequency temperature variability at Fukue Island located southwest of the Tsushima Straits. Journal of Oceanography, vol. 56, p. 141-152.

Moriyasu, S., 1972: The Tsushima Current. In, Stommel, H. and Yoshida, K. eds., Kuroshio: Its Physical Aspects, p. 353-369. University of Tokyo Press, Tokyo.

Nakajima, K. and Katayama, H., 1992: Surface sediments off Sakata and Akita. In, Okamura, Y. ed., Preliminary Reports of Geological Mapping Program of the Continental Shelf Areas in Japan in 1991, p. 105-130. Geological Survey of Japan, Tsukuba. (in Japanese)

Oba, T., Kato, M., Kitazato, H., Koizumi, I., Omura, A., Sakai, T. and Takayama, T., 1991: Paleoenvironmental changes in the Japan Sea during the last 85,000 years. Paleoceanography, vol. 6, p. 499-518.

Oba, T., Murayama, M., Matsumoto, E. and Nakamura, T., 1995: AMS ${ }^{14} \mathrm{C}$ ages of Japan Sea cores from the Oki Ridge. The Quaternary Research, vol. 34, p. 289-296. (in Japanese with English abstract)

Oda, M., 1989: Preliminary report on planktic foraminiferal assemblages in surface sediments off northern Noto Peninsula. In, Arita, M. and Okamura, Y. eds., Preliminary Reports of Geological Mapping Program of the Continental Shelf Areas in Japan in 1988, p. 122-124. Geological Survey of Japan, Tsukuba. (in Japanese)

Oda, M., 1991: Preliminary report on planktic foraminiferal assemblages in surface sediments around the Sado Island. In, Okamura, Y. ed., Preliminary Reports of Geological Mapping Program of the Continental Shelf Areas in Japan in 1990, p. 133-135. Geological Survey of Japan, Tsukuba. (in Japanese)

Oda, M. and Ikehara, K., 1987: Preliminary report on planktic foraminiferal assemblages in surface sediments off the northern San'in region. In, Arita, M., Okuda, Y. and
Moritani, T. eds., Preliminary Reports of Geological Mapping Program of the Continental Shelf Areas in Japan in 1986, p. 162-164. Geological Survey of Japan, Tsukuba. (in Japanese)

Oda, M. and Ikehara, K., 1988: Preliminary report on planktic foraminiferal assemblages in surface sediments off the northeastern San'in region. In, Arita, M. and Moritani, T. eds., Preliminary Reports of Geological Mapping Program of the Continental Shelf Areas in Japan in 1987, p. 167-169. Geological Survey of Japan, Tsukuba. (in Japanese)

Oda, M. and Takemoto, A., 1992: Planktonic foraminifera and paleoceanography in the domain of the Kuroshio Current around Japan during the last 20,000 years. The Quaternary Research, vol. 31, p. 341-357. (in Japanese with English abstract)

Oda, M. and Xu, X., 1992: Preliminary report on planktic foraminiferal assemblages in surface sediments off western Akita Prefecture. In, Okamura, Y. ed., Preliminary Reports of Geological Mapping Program of the Continental Shelf Areas in Japan in 1991, p. 214-216. Geological Survey of Japan, Tsukuba. (in Japanese)

Ogawa, Y., 1983: Seasonal changes in temperature and salinity of water flowing into the Japan Sea through the Tsushima Straits. Bulletin of the Japanese Society of Fisheries Oceanography, vol. 43, p. 1-8. (in Japanese with English abstract)

Ozawa, H., 2003: Japan Sea ostracod assemblages in surface sediments: their distribution and relationships to water mass properties. Paleontological Research, vol. 7, p. 257 274.

Saito, T., Thompson, P.R. and Breger, D., 1981: Systematic Index of Recent and Pleistocene Planktonic Foraminifera, 190 p. University of Tokyo Press, Tokyo.

Sawara, T. and Hanzawa, Y., 1979: Distribution of water type in the East China Sea. Sea and Sky, vol. 54, p. 135-148. (in Japanese with English abstract)

Takayanagi, Y. and Oda, M., 1983: Distributions of planktic foraminifera in surface sediments east of Honshu. Marine Sciences Monthly, vol. 15, p. 138-144. (in Japanese)

Takei, T., Minoura, K., Tsukawaki, S. and Nakamura, T., 2002: Intrusion of a branch of the Oyashio Current into the Japan Sea during the Holocene. Paleoceanography, vol. 17, 10.1029/2001PA000666.

Tsukawaki, S., Kamiya, T., Kato, M., Matsuzaka, T., Naraoka, H., Negishi, K., Ozawa, H. and Ishiwatari, R., 1997: Preliminary results from the R.V. Tansei-maru cruise KT95-14 Leg 2 in the southern marginal area in the Japan SeaPart I: Sediments, benthic foraminifers and ostracodes. Bulletin of the Japan Sea Research Institute, Kanazawa University, no. 28, p. 13-43.

Tsukawaki, S., Ozawa, H., Domitsu, H., Hirano, K., Maeda, T., Tomii, Y., Saito, S., Xu, X., Kamiya, T., Kato, M. and Oda, M., 2001: Preliminary results from the R.V. Tansei-maru cruise KT99-14 in the central and northeastern marginal parts of the Japan Sea-Sediments, benthic and planktonic foraminifers, and ostracodes (Part 1: Surface sediments). Bulletin of the Japan Sea Research Institute, Kanazawa University, no. 32, p. 1-28.

Uda, M., 1934: The results of simultaneous oceanographical investigations in the Japan Sea and its adjacent waters in May and June, 1932. Journal of the Imperial Fisheries Experimental Stations, vol. 5, p. 57-190. (in Japanese with English abstract)

Ujiié, H. and Ujiié, Y., 1999: Late Quaternary course change of 
the Kuroshio Current in the Ryukyu Arc region, northwestern Pacific Ocean. Marine Micropaleontology, vol. 37, p. $23-40$.

Wang, P., Zhang, L., Zhao, Q., Min, Q., Bian, Y., Zheng, L., Cheng, X. and Chen, R., 1988: Foraminifera and Os- tracoda in Bottom Sediments of the East China Sea, 438 p. Ocean Press, Beijing. (in Chinese with English abstract)

$\mathrm{Xu}, \mathrm{X}$. and Oda, M., 1999: Surface-water evolution of the East China Sea during the last 36,000 years. Marine Geology, vol. 156 , p. 285-304. 